\title{
New records of symbiotic shrimps of the genus Dasycaris Kemp, 1922 from Vietnam and Papua New Guinea, with redescription of D. ceratops Holthuis, 1952 (Crustacea: Decapoda: Pontoniinae)
}

\author{
Новые находки симбиотических креветок рода Dasycaris \\ Kemp, 1922 из Вьетнама и Новой Гвинеи с переописанием \\ D. ceratops Holthuis, 1952 (Crustacea: Decapoda: Pontoniinae)
}

\section{Zdeněk Ďuriš \\ Зденек Ауриш}

Department of Biology and Ecology, Faculty of Science, University of Ostrava, Chittussiho 10, 71000 Ostrava, Czech Republic. E-mail: zdenek.duris@osu.cz

KEY WORDS. Dasycaris ceratops, Dasycaris zanzibarica, Indo-Pacific, Pennatularia, symbioses, sexual dimorphism.

КЛЮЧЕВЫЕ СЛОВА. Dasycaris ceratops, Dasycaris zanzibarica, Indo-Pacific, Pennatularia, симбиоз, половой диморфизм.

ABSTRACT. The pontoniine shrimp Dasycaris ceratops is for the first time reported from Vietnam in the South China Sea. The hydroid Lytocarpia sp. occupied by some juvenile specimens is a new host for the species. The species is redescribed and illustrated here based on an adult male collected from the sea-pen Virgularia sp. The examination of the present male specimen of $D$. ceratops contributes to the knowledge on intraspecific variability of the rostral and carapacial teeth armament, and allows to report on previously undescribed structures, e.g., the anteroventral denticulation of the carapace, the fine denticulation of the cutting edges on the first pereiopods, the movable anteroventral lobe on the first abdominal pleurae and the unique subdivision of the first male pleopodal endopod. The colour in life and some morphological characters of juveniles are described. Dasycaris ceratops is compared with specimens of $D$. zanzibarica from Vietnam, Australia and Papua New Guinea. Madang lagoon in northeastern Papua New Guinea, the southern Bismarck Sea, is a new country record for the latter species.

РЕЗЮМЕ. Понтониинная креветка Dasycaris ceratops впервые отмечена для Вьетнама в ЮжноКитайском море. Впервые в качестве хозяина указывается гидроид Lytocarpia sp., на котором отмечены некоторые ювенильные эемпляры. Вид переописан и иллюстрирован на примере взрослого самца, собранного с морского пера Virgularia sp. Исследование данного экземпляра расширяет сведения о внутривидовой изменчивости набора зубцов на роструме и карапаксе и позволяет описать ранее неописанные структуры, такие как антеровентральные зубчики карапакса, тонкую зазубренность режущих краев переопод первой пары, подвижную антеровентральную лопасть на первых абдоминальных плеврах и уникальное подразделение эндопода плеопода первой пары самца. Описаны прижизненная окраска и некоторые морфологические признаки ювенильных особей. Проведено сравнение Dasycaris ceratops с экземплярами D. zanzibarica из Вьетнама, Австралии и Папуа Новой Гвинеи. Лагуна Маданг на северо-востоке Папуа Новой Гвинеи (южная часть моря Бисмарка) является новым местонахождением данного вида для страны.

\section{Introduction}

Dasycaris Kemp, 1922 is a genus of the Indo-West Pacific pontoniine shrimps, presently containing four species of somewhat morphologically aberrant shrimps symbiotic with pennatularian sea-pens, antipatharian black corals, and hydroids [Bruce, 1974, 1983; Chace, Bruce, 1983; Li, 2001]. The genus Dasycaris was originally established by Kemp [1922] for D. symbiotes Kemp, 1922 based on a male-female pair of specimens from India. The larger specimen, the ovigerous female, was described in details and figured in toto [Kemp, 1922: pl. 9], while some body parts were also figured [same: Figs 76-77] but not directly attributed to either specimen. Only the abdominal pleurae were compared between the sexes, demonstrating sexual dimorphism in the shape of the first two pleurae in this species. Later, Monod [1976] provided a short notice on another ovigerous female of the species collected from Nouméa, with figures of the carapace, eye, abdomen, mandible, the third maxilla and the first chelipeds [Monod, 1977: Figs 54-60].

Subsequently, three other species were described, D. doederleini (Balss, 1924), D. ceratops Holthuis, 
1952, and D. zanzibarica Bruce, 1973. The original description, and the only report, of $D$. doederleini, based on a single ovigerous female from Japan, was very brief and only provided with a single line-figure of the carapace and abdomen [Balss, 1924]. Similarly, D. ceratops was described by Holthuis [1952] on the basis of a single ovigerous female from Borneo Bank, Makassar Strait. Detailed description, as well as figures of the total lateral aspect and some body parts, including most mouth appendages were provided [Holthuis, 1952]. Later, Bruce [1977] contributed to the knowledge of this species with a short notice on a juvenile female collected from antipatharian coral at Queensland, and also figured the carapace with eye and abdomen [Bruce, 1977]. Only the original study on D. zanzibarica by Bruce [1973] is based on a wider series of 9 specimens containing also mature representatives of both sexes. This well-illustrated report also draws attention to the variability of the relatively lowlobate carapaces [Bruce, 1973: Figs. 1-6]. This also is the only Dasycaris species for which the male gonopods have been described and figured [Bruce, 1973]. Later, Bruce [1991] provided a figure of a high-lobate ovigerous female from New Caledonia.

As a part of investigation of the symbiotic marine shrimps of Vietnam in co-operation with the VietnamRussian Tropical Centre (principal investigator Prof. T.A. Britaev), a small series of $D$. ceratops specimens was collected by the author in 2008. The examination of a single mature male specimen collected from a seapen, and several juveniles found thereon as well as on a hydroid colony, allow to detect some distinctions from published reports of the species, as well as to point out some interesting unpublished structures typical for, at least, the present species. The species is recorded for the first time from Vietnam and also from a new host.

Subsequently, specimens of another species, D. zanzibarica, were also collected from Vietnam, and others were obtained during international expeditions to the Great Barrier Reef, Queensland, Australia (CReefs Lizard Island Expedition, 2010), and Madang, Papua New Guinea (Papua-Niugini Expedition, 2012). Morphological and colour diversity is discussed, and colour photographs of both species are provided for comparative purposes.

The following abbreviations are used in the text: MNHN - Muséum National d'Histoire Naturelle, Paris, France; UO - University of Ostrava, Czech Republic; PoCL — post-orbital carapace lenght.

This paper is dedicated, in the occasion of their jubilees, to two 'Very-Important-Persons' in my life Nikolai A. Zarenkov and Rudolf N. Burukovsky, my teachers, and, I allow myself to believe, also good friends - to celebrate their outstanding contributions to decapod crustacean systematics, and their assistance in my graduate and post-graduate studies and subsequent carcinological career.

\section{Systematics}

Family Palaemonidae Rafinesque, 1815 Subfamily Pontoniinae Kingsley, 1878

Genus Dasycaris Kemp, 1922

\section{Dasycaris ceratops Holthuis, 1952}

Figs. 1-5, 6a-e. 173, Fig. 5.

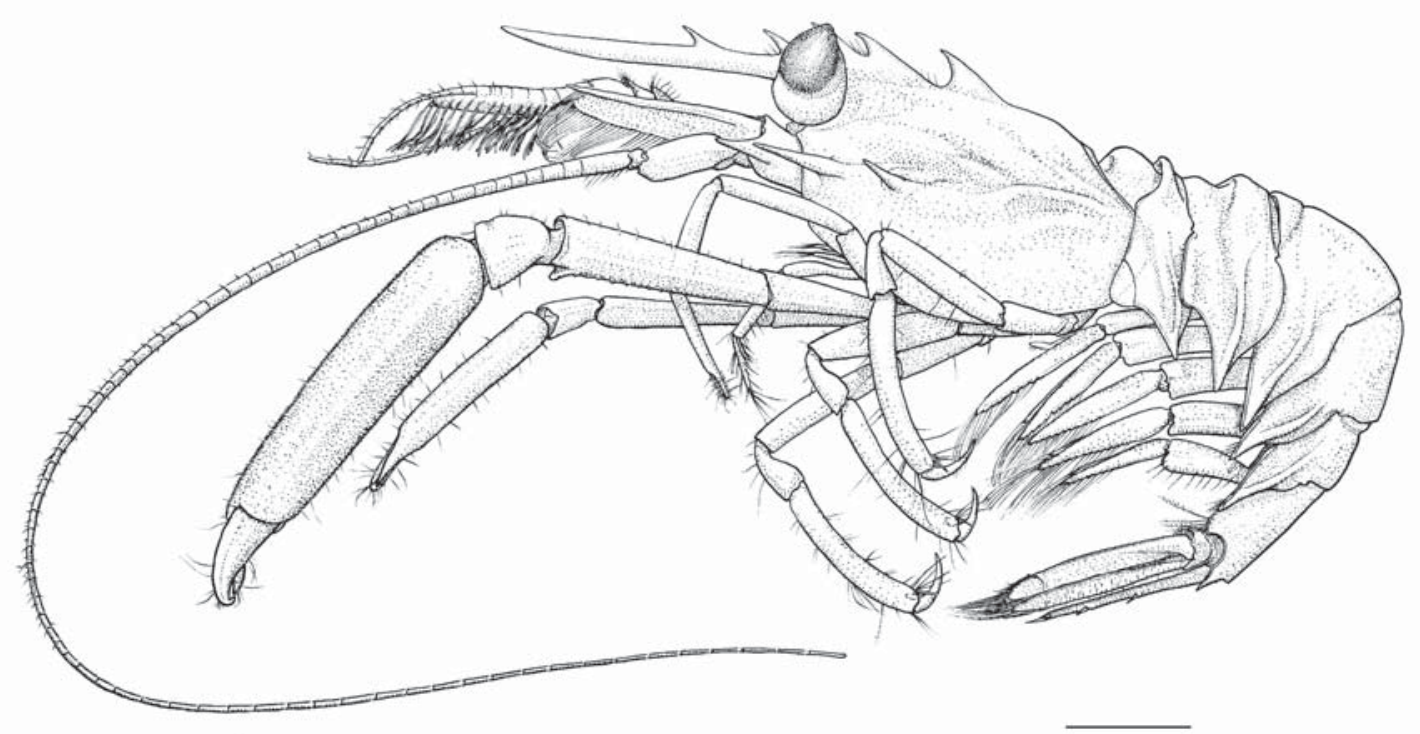

Fig. 1. Dasycaris ceratops Holthuis, 1952, male, Nhatrang Bay, Vietnam, total aspect, lateral. Scale bar - $1 \mathrm{~mm}$.

Рис. 1. Dasycaris ceratops Holthuis, 1952, самец, залив Нячанг, Вьетнам, общий вид, вид сбоку. Масштабная линейка 1 мм. 


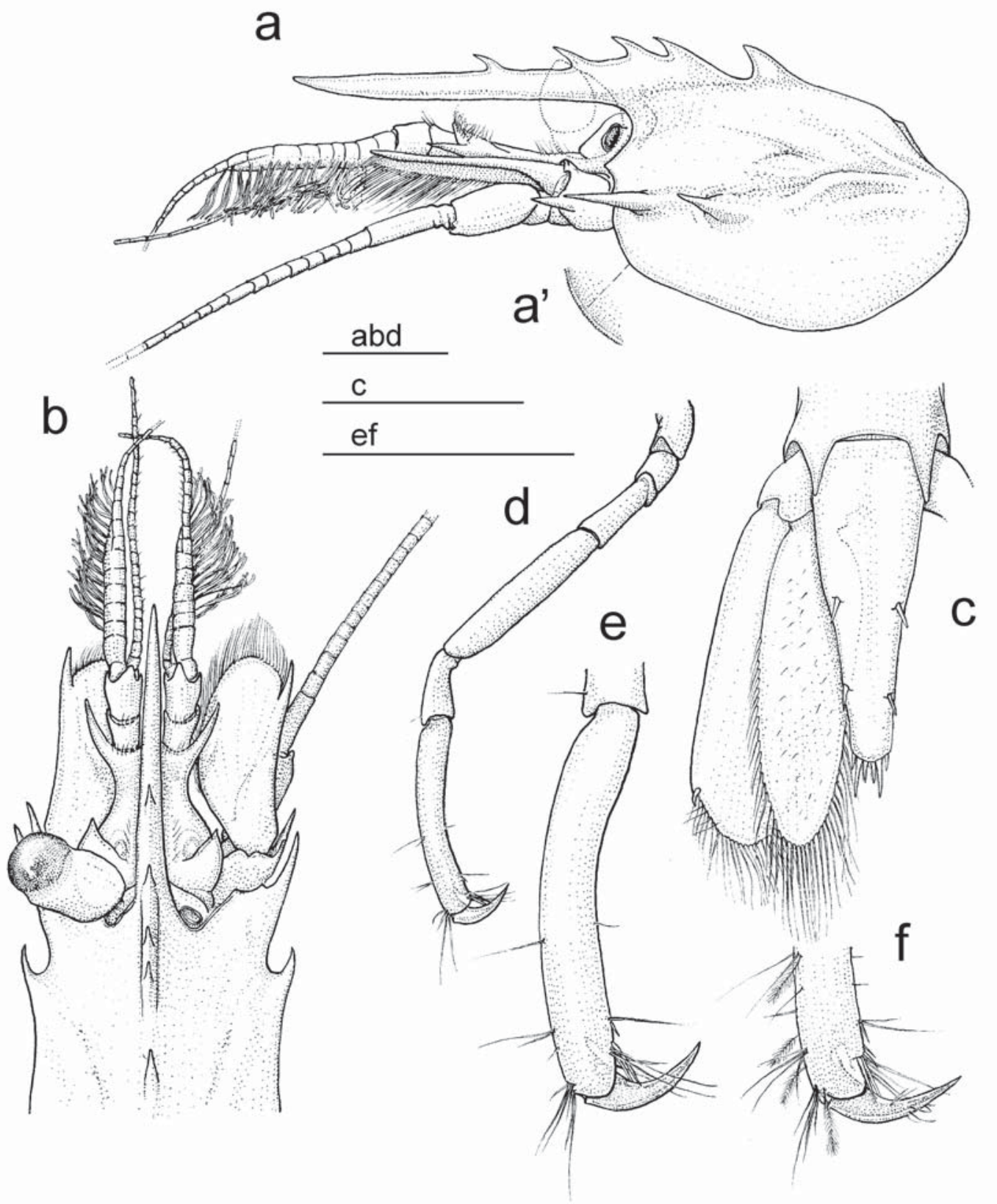

Fig. 2. Dasycaris ceratops Holthuis, 1952, male, Nhatrang Bay, Vietnam; a - carapace and antennae, lateral; eye indicated by dotted line; a' - detail, denticulate anteroventral angle of carapace; b - carapace, eye, and antennae, dorsal; c - telson and uropod, dorsal; $d-$ third pereiopod, lateral; e - same, propodus and dactylus; $\mathrm{f}$ - fifth pereiopod, distal propodus and dactylus, lateral. Scale bars - $1 \mathrm{~mm}$ (a' - unscaled).

Pис. 2. Dasycaris ceratops Holthuis, 1952, самец, залив Нячанг, Вьетнам; а - карапакс и антенны, вид сбоку; глаз обозначен точечной линией; a' — деталь, зазубренный антеровентральный угол; b — карапакс, глаз и антенны, дорсальный вид; с — тельсон и уропод, дорсальный вид; d - переопод третьей пары, вид сбоку; е - то же, пропод и дактиль; f - переопод пятой пары, дистальная часть пропода и дактиль, вид сбоку. Масштабная линейка 1 мм (a' - немасштабировано).

MATERIAL EXAMINED. 2 juveniles, UO 118B-Vn08, Mun Is., Nhatrang Bay, Vietnam, 14 Sep. 2008, from Lytocarpia sp. (Hydrozoa), flat sandy bottom, depth $12 \mathrm{~m}$, coll. Z. Duriš. - 1 male, 2 juveniles, UO 126-Vn08, Nhatrang Bay, Mun Is., 16 Sep. 2008, from 2 colonies of Virgularia sp. (Pennatularia), flat sandy bottom, depth $12.3 \mathrm{~m}$, coll. Z. Durišs.

DESCRIPTION OF ADULT MALE. Medium sized pontoniine shrimp with well calcified subcylindrical body (Fig. 1). Carapace (Figs. 1, 2a) smooth, some- what areolated posterolaterally. Rostrum styliform, straight, far overreaching antennular peduncle (Figs. 1, 2a,b), 1.3 times longer that postorbital carapace length, bearing two slender, widely separated dorsal teeth on proximal 0.2 and 0.4 of length; ventral margin unarmed. Carapace dorsally with two closely spaced teeth slightly larger than rostral ones; large acute epigastric tooth present on dorsal midlength of carapace. Orbit 


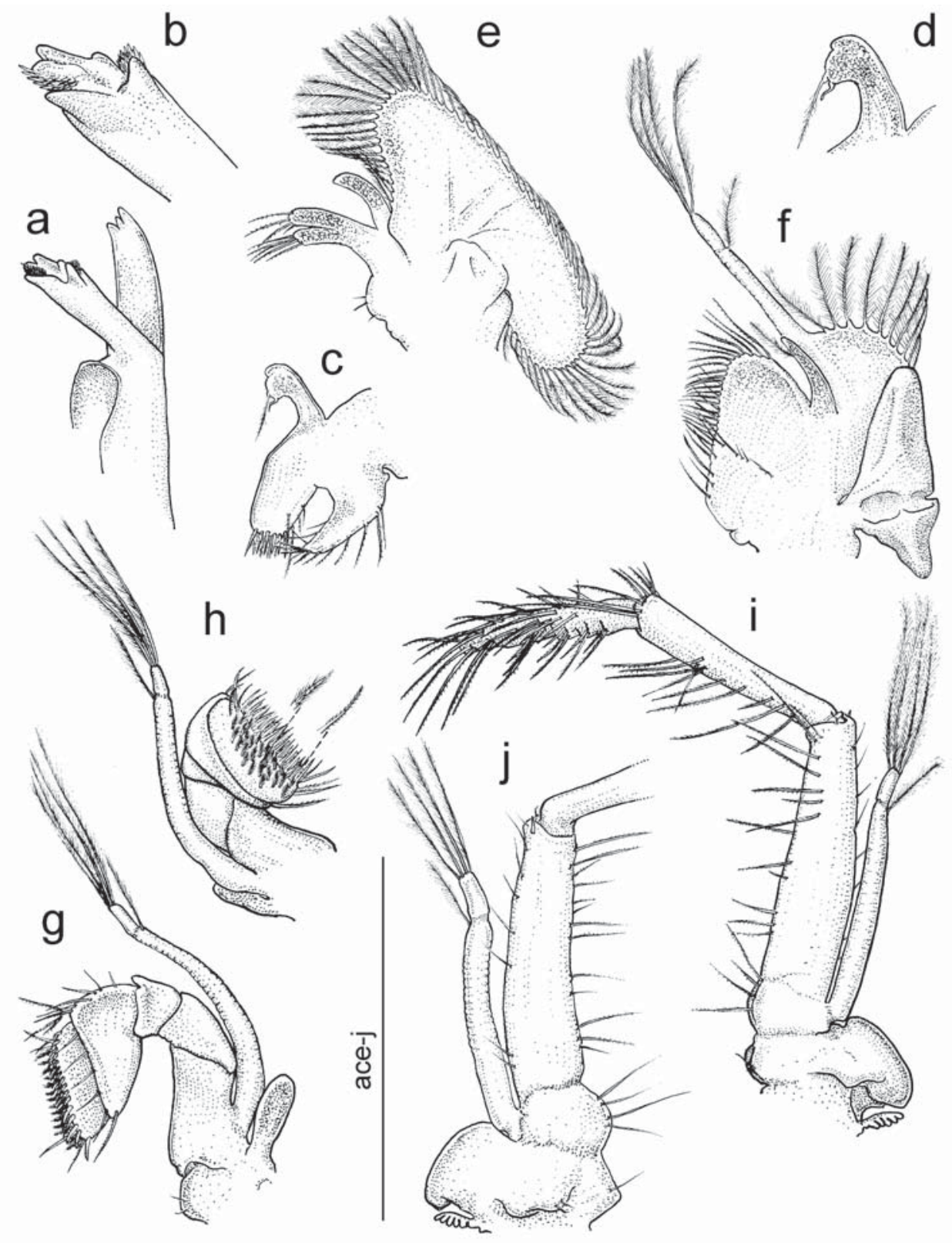

Fig. 3. Dasycaris ceratops Holthuis, 1952, male, Nhatrang Bay, Vietnam, mouthparts (from the right side); a - mandible; b, same, molar process; c - maxillula; $\mathrm{d}$ - same, palp; e — maxilla; $\mathrm{f}$ - first maxilliped; $\mathrm{g}$ - second maxilliped, outer aspect; $\mathrm{h}$ - same, inner aspect; $\mathrm{i}$ - third maxilliped, lateral; $\mathrm{j}$ - same, inner aspect of proximal segments.

Рис. 3. Dasycaris ceratops Holthuis, 1952, самец, залив Нячанг, Вьетнам, ротовые придатки (правые); а — мандибула; b - то же, молряный отросток; с — максилула; d - то же, пальпа; е — максилла; $\mathrm{f}$ - максилипед первой пары; $\mathrm{g}$ - максилипед второй пары, внешняя сторона; $\mathrm{h}$ - то же, внутренняя сторона; $\mathrm{i}$ - максилипед третьей пары, вид сбоку; $\mathrm{j}$ - то же, внутренняя сторона проксимальных сегментов.

feebly developed, inferior orbital angle subacute. Large, slender submarginal antennal spine reaching distal margin of antennal basicerite; hepatic spine much smaller, lying posteriorly at same level as hepatic spine; supraorbital spines absent. Anteroventral angle of carapace rounded, with margin finely denticulate (Fig. 2a').

Fourth thoracic sternite unarmed.

Abdominal segments (Fig. 1) smooth. Pleura of first five abdominal segments all produced ventrally to acute processes with obtuse median carina; first and second pleurae obtusely angulate anteroventrally, first pleura with movable membranous anteroventral plate; first and second segments slightly produced dorsally, third segment not produced in dorsal midline; fifth segment 0.6 times length of sixth one, latter 1.5 times longer than deep, subcylindrical, slightly curved, posterolateral angle strongly produced, acute, posteroventral angle less produced, obtusely angulate. 


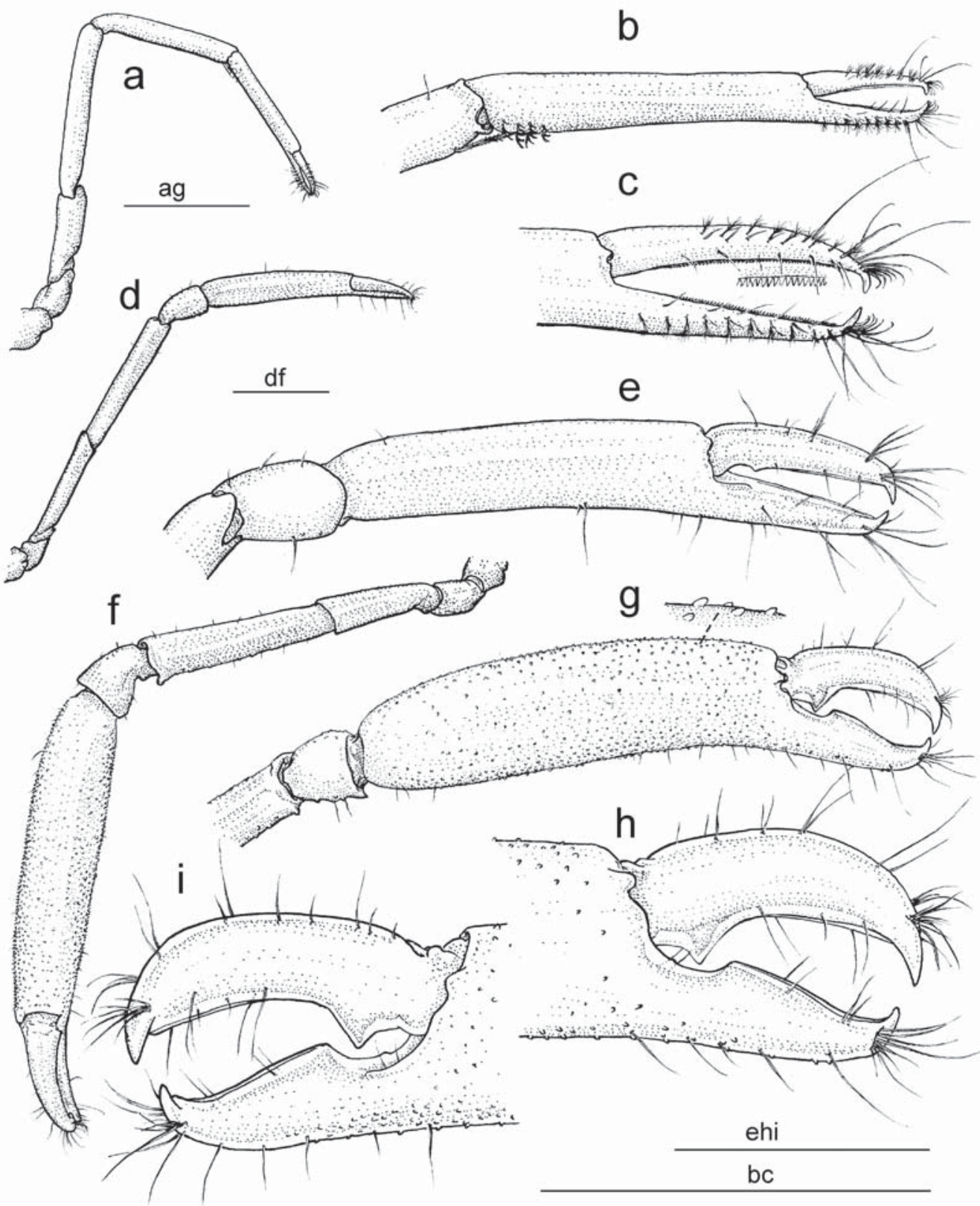

Fig. 4. Dasycaris ceratops Holthuis, 1952, male, Nhatrang Bay, Vietnam; a - right first pereiopod, lateral; b - same, distal segments, lateral; c - same, tips of fingers, with detail of dactylar cutting edge; $\mathrm{d}$ - minor second pereiopod, lateral; $\mathrm{e}$ - same, chela; $\mathrm{f}$ major second pereiopod, lateral; g - same, distal merus, carpus and chela, mesial, with detail of dorsal tuberculation of palm; $\mathrm{h}$ - same, dispal palm and fingers; i, same, lateral.

Рис. 4. Dasycaris ceratops Holthuis, 1952, самец, залив Нячанг, Вьетнам; a — правый переопод первой пары, вид сбоку; b - то же, дистальные сегменты, вид сбоку; с — то же, концы пальцев клешни с показом деталей режущего края дактиля; $\mathrm{d}$ - малая переопода второй пары, вид сбоку; е - то же, клешня; f - большая переопода второй пары, вид сбоку; g - то же, дистальная часть мероподита, карпопоподита и клешня, мезиальный вид с деталями дорсальной туберкулярной скульптуры клешни; $\mathrm{h}-$ то же, дистальная часть клешни; і - то же, вид сбоку.

Telson (Fig. 2c) about 1.3 times longer that dorsal length of sixth abdominal segment and 2.7 times longer than broad, tapering posteriorly with feebly concave posterolateral margins; two pairs of submarginal dorsal spines small, less than 0.1 of telson length, situated at about 0.5 and $0.75-0.8$ of telson length; posterior margin rounded, with three pairs of spines; lateral spines smaller than dorsal spines, submedian setose, subequal to dorsal spines, intermediate spines short and stout, about twice length of submedian spines.

Eyes (Figs. 1, 2b) well developed, with cornea oblique, ovoid, with conical dorsal projections; eyestalk slightly flattened, about 1.3 times as long as wide; no accessory pigment spot visible. 
Antennular peduncle (Fig. 2a,b) slightly shorter than postorbital carapace length, and much shorter than rostrum. Basal segment distinctly constricted by deep lateral concavity on distal third, about 2.2 times longer medially than wide basally; stylocerite short and bluntly leaf-like, not reaching to middle of segment length, with statocyst normally developed; distolateral angle armed with slender acute tooth exceeding distal border of intermediate segment; small acute tooth present at middle of medial ventral border; intermediate and distal segments about 0.3 and 0.4 of medial length of basal segment, respectively. Upper flagellum biramous, with rami fused proximally for first 7 segments, shorter free ramus consisting of 3 segments, about 15 groups of aesthetascs present on stouter part of flagellum; longer free ramus consisting of up to 15 slender segments. Lower flagellum bearing over 20 segments.

Antenna (Fig. 2a,b) with basicerite bearing strong lateral spiniform tooth. Scaphocerite exceeding antennular peduncle by length of distolateral spine; lateral border gently concave with strong distolateral tooth more than 0.2 of lateral border length and barely exceeding anterior margin of lamella; lamella 2.4 times longer than broad, with anterior and medial margins continuously rounded; carpocerite short and stout, subcylindrical, and reaching approximately to middle of scaphocerite; antennal flagellum normally developed, long.

Mandible (Fig. 3a,b) without palp; molar process elongate, with 5 blunt distal teeth and small dorsal and ventral groups of setae; incisor process slender, with 3 small teeth distally.

Maxillula (Fig. 3c,d) normal; palp slender, distally expanded, rounded, feebly bilobed, with long setulose seta and small hooked seta on inner lobe; upper lacinia robust, slightly tapering proximally, and bearing about 9 short stout serrulate spines distally; lower lacinia strongly tapering distally, with around 15 setae evenly distributed along margins.

Maxilla (Fig. 3e) with slender non-setose palp; proximal endite obsolete, broadly rounded; distal endite elongate, deeply bilobed and sparsely setose distally; scaphognathite well developed, moderately broad, about 2.4 times longer than wide.

First maxilliped (Fig. 3f) with elongated slender palp bearing single short plumose subterminal seta; basal and coxal endites fused, forming broad lamina, without any notch in medial border, latter provided with serrulate setae; exopod well developed, with 4 long plumose terminal setae and shorter subterminal one, constricted distally just behind subterminal seta and, thus, appearing subdivided; caridean lobe large, with plumose marginal setae; epipod large, bilobed.

Second maxilliped (Fig. 3g,h) with terminal segment subrectangular, elongate, almost 3 times wider than long; with medial border and distoventral side armed with rows of short stout serrulate setae, and with several longer ones distally; penultimate segment broadly subtriangular, with distal margin bearing series of separately set long simple setae; carpus, merus and ischio-basis normal; exopod well developed, setose and subdivided similarly to exopod of first maxilliped; coxa rounded medially, with elongated simple epipod, without podobranch.

Third maxilliped (Fig. 3i,j) slender; antepenultimate segment with a small movable spine dorsolaterally, segment fused from merus to basis, with ischiobasal line of junction feebly indicated, combined segment slender, about 4.5 times longer than broad, medial border sparsely setose; penultimate segment slender, about 0.7 times length of preceding segment, and 5 times longer than wide; terminal segment 0.8 of length of penultimate segment, slender and tapering, about 5.5 times longer than wide; medial and distal border of penultimate segment with few long finely serrulate setae, distal segment more densely setose with longer setae distally and shorter setae proximally, latter arranged ventrally to transverse rows; basis produced medially, rounded, with few serrulate setae; coxa widely trianguar medially, with single seta; large, broadly rounded lateral lobe and small arthrobranch composed of about 5 low lamellae, present laterally on coxa. Exopod slender, falling to reach distal margin of antepenultimate segment, setose and subdivided similarly to exopods of first and second maxillipeds.

First pereiopod (Fig. 4a-c) slender and extends beyond antennular peduncle by length of chela. Chela slender, long, about 7.5 times longer than basal height; palm subcylindrical and more than 5 times longer than basal height; fingers slender, tapering and slightly compressed, about 0.4 of palm length, with strongly hooked tips; proximal 0.2 of cutting edges entire, remaining 0.8 of cutting edges finely denticulate with about 60 denticles, but otherwise unarmed. Carpus slightly stouter than chela, subcylindrical, about 6 times longer than wide, merus as slender as carpus, but slightly longer. Ischium half length of merus and slightly longer than basis, coxa short and stout, without distinct median lobe.

Second pereiopods (Fig. 1) robust, similar but markedly unequal. Minor second pereiopod (Fig. 4d,e) exceeding antennular peduncle by chela. Chela about half length of major chela. Palm subcylindrical, not markedly swollen proximally and about 4 times longer than high distally. Dactylus half length of palm and similar to dactylus of major second pereiopod but more elongate, slender, and with tooth on cutting edge less developed. Fixed finger lacking teeth, cutting edge entire throughout its length. Carpus, merus and ischium similar to major second pereiopod but less robust, smooth, unarmed.

Major cheliped (Fig. 4f,i) exceeding antennular peduncle by end of merus. Palm of chela of major second pereiopod finely tuberculate, subcylindrical, about 3.7 times longer than wide. Dactylus about 0.4 of palm length, stout and slightly compressed, arched, with strongly rounded dorsal margin and hooked tip; proximal 0.25 of cutting edge bearing single large triangular tooth, distal cutting edge entire. Fixed finger more 


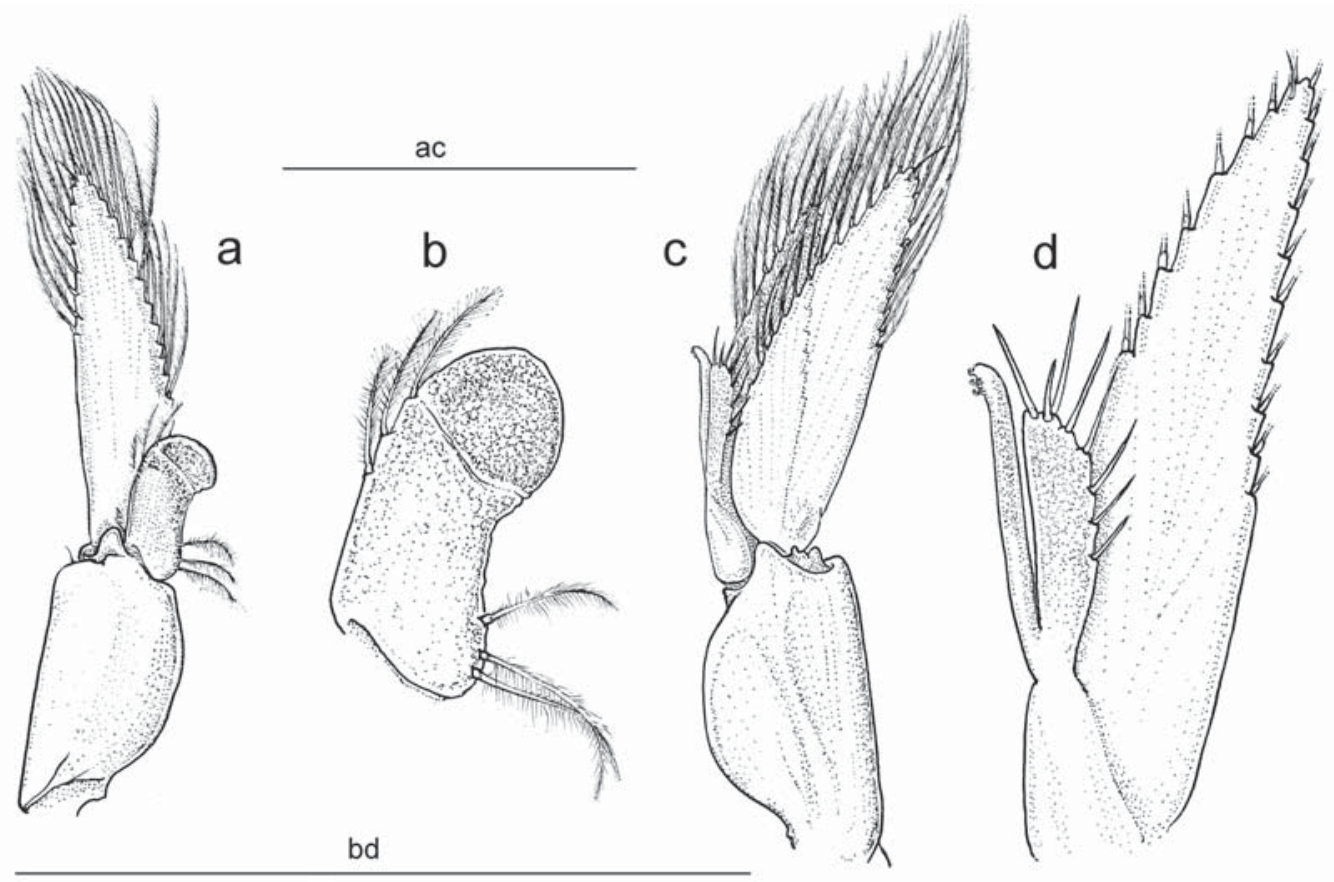

Fig. 5. Dasycaris ceratops Holthuis, 1952, male, Nhatrang Bay, Vietnam; a — first male pleopod, total aspect; b — same, endopod; $\mathrm{c}$ - second male pleopod, total aspect; $\mathrm{d}$ - same, endopod. Scale bars - $1 \mathrm{~mm}$.

Fig. 5. Dasycaris ceratops Holthuis, 1952, самец, залив Нячанг, Вьетнам ; а — плеопод первой пары, общий вид; b - то же, эндопод; с - плеопод второй пары, общий вид; $\mathrm{d}$ - то же, эндопод. Масштаб 1 мм.

straight, distally hooked, with entire distal 0.6 of cutting edge rising proximally to low tooth, proximal part formed as shallow notch with mesial socket opposing dactylar tooth. Carpus short, with length subequal to its hight and about 0.2 times length of palm, expanded distally, scarcely granulated ventrally and dorsally, with small acute distoventral tooth. Merus subcylindrical, 3.6 times longer than wide and 0.6 times length of palm, ventrally granulated, distoventral angle with subacute tooth. Ischium unarmed, 0.6 times length of merus.

Ambulatory pereiopods robust, with third pereiopod (Fig. 2d,e) exceeding tip of scaphocerite by length of dactylus. Third pereiopod dactylus robust but slightly compressed, simple, feebly hooked but straighter distally, about three times longer than basal width. Propodus stout and distinctly curved, uniformly high thrughout, about 6.5 times longer than wide, with pair of long distoventral spines and single short subterminal spinule; propodus with few simple long setae distally and some ones on distal half of dorsal and ventral borders. Carpus about 0.4 of propod length, expanded distally; merus subequal to propodus length, and about 5.5 times longer than broad, unarmed; ischium simple, about 0.6 times length of merus; basis and coxa short, unarmed. Fourth and fifth pereiopods similar to third pereiopods, propodus of fifth pereiopod (Fig. 2f) with 3 subterminal spinules proximally to pair of long distoventral spines, and with some plumose setae distodorsally in addition to simple ones.

Endopod of first male pleopod (Fig. 5a,b) 0.4 of exopod length, stout and flattened, 2.3 times longer than greatest width; endopod subdivided by oblique suture on distal $0.6-0.7$ of length to subrectangular basal part and subcircular, medially produced, apex; basal part with 3 plumose setae proximally on mesial border, and with 3 plumose setae distally on lateral margin. Second male pleopod (Fig. 5c,d) with slender appendix interna exceeding midlength of exopod; appendix masculina falling short to appendix interna but distinctly stouter, about 4 times longer than broad in middle, with 3 simple terminal setae and series of 5 similar ones on distal 0.6 of lateral border.

Uropods (Fig. 2c) normal. Basipodite unarmed laterally. Exopod about 3 times longer than wide with feebly convex, entire, lateral border terminating distally in short mobile spine, without fixed tooth laterally. Endopod more slender, about 3.5 times longer than broad.

MEASUREMENTS. Male: post-orbital carapace length (PoCL) $2.1 \mathrm{~mm}$; total body length $11 \mathrm{~mm}$; rostrum lenth $2.8 \mathrm{~mm}$; rostrum formula $(1+2)+2 / 0$.

JUVENILES.The juveniles, both males and females (PoCL around $1.4 \mathrm{~mm}$ ) collected from the sea-pen and hydroid are mutually identical in their shape, and closely similar to the male described above. Their rostrum and carapacial teeth are well developed, identical in the shape and number to the large male (above). The abdominal pleura are more sharply produced, pleurae III are bilobed in juvenile males and juvenile females, with the lobes triangular, and the anterior lobe shorter than the posterior ones, but proportionally larger than those of the large male; pleurae III-V are simple, acutely 


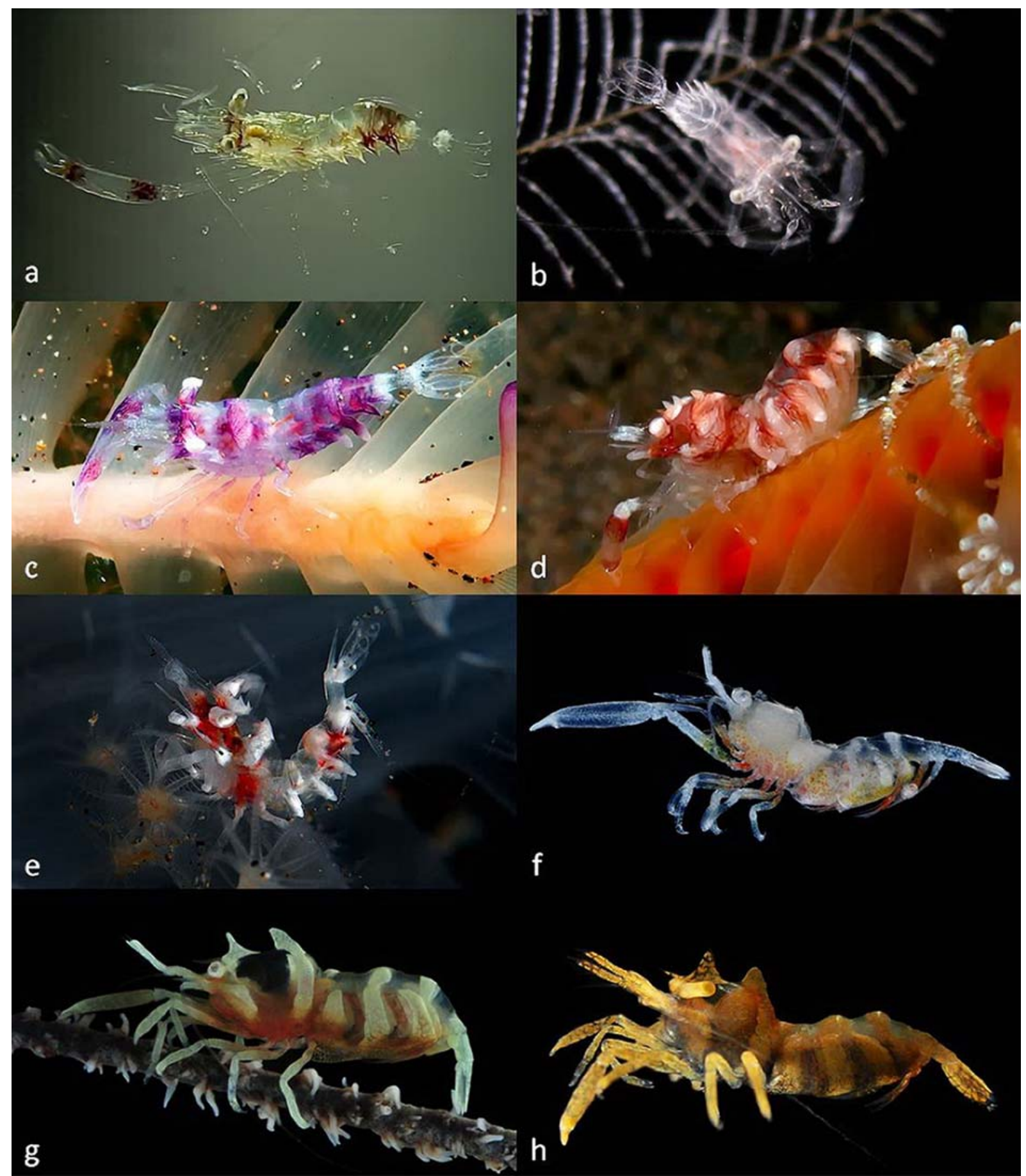

Fig. 6. Colour pattern of Dasycaris spp., a-e - D. ceratops Holthuis, 1952: a, b - Nhatrang Bay, Vietnam - a, male UO 126-Vn08, b - juvenile UO 118B-Vn08 on Lytocarpia sp. (Hydrozoa); c-e - male, ovigerous female and juvenile, resp. (not collected), from Pteroeides sp. (Pennatularia), Philippines; f-h - D. zanzibarica Bruce, 1973, ovigerous females: f, g - Madang, Papua New Guinea, MNHN IU-2013-11019 and 10039, resp. (g - on Cirripathes sp., Antipatharia); h - UO 40-Vn10, Nhatrang Bay, Vietnam. Photos: a, b, $\mathrm{h}-$ author, c-e - A. Ryanskiy, f, g- A. Anker.

Fig. 6. Прижизненная окраска Dasycaris spp., a-e - D. ceratops Holthuis, 1952: a, b - залив Нячанг, Вьетнам — а, самец UO 126-Vn08, b - ювенильный экземпляр UO 118B-Vn08 с Lytocarpia sp. (Hydrozoa); c-e - самец, яйценосная самка и ювенильный экземпляр соответсвенно (не собраны), с Pteroeides sp. (Pennatularia), Филиппины; $\mathrm{f}-\mathrm{h}-\mathrm{D}$. zanzibarica Bruce, 1973, яйценосная самка: f, g — Маданг, Папуа Новая Гвинея, MNHN IU-2013-11019 и 10039, соответственно (g — c Cirripathes sp., Antipatharia); $\mathrm{h}$ UO 40-Vn10, залив Нячанг, Вьетнам. Фото: a, b, h - автор, с-е - А. Рянский, f, g- А. Анкер. 
produced. The juvenile male examined has the first pleopodal endopod similar to that of the large male, subdivided.

COLOUR. Adult male (Fig. 6a): initially, when collected, the darker patches were purple, later changing to brown; body and major chela largely semi-transparent, slightly yellowish tinged, and with sparse dark brown and white patches; other appendages transparent; in adult male a distinct brown transverse patch connecting bases of eyes and rostrum, similar patches present on abdominal pleurae III and posteriorly on tergum and pleurae of abdominal segment IV, and as diffused transverse distal and proximal bands on palm of major chela; diffuse white patches present mainly on eyes and on abdominal pleurae I and II, posterodorsally on abdominal segment $\mathrm{V}$ and transversally on base of tail fan; latter otherwise transparent; when relaxed, large white chromatophores may expand dorsally on tail fan arranged into irregular transverse bands.

Juvenile specimens (Fig. 6b), PoCL around $1.4 \mathrm{~mm}$ : body semi-transparent, eyes whitish connected by narrow transverse white band, abdominal pleurae sharply outlined by white line, intestine white.

Photographed specimens from Philippines. Male (Fig. 6c): cornea bright white; body generally semitransparent, with whitish tinge, eyestalks and major chela widely covered by dense network of purple and reddish, almost violet, softly diffused lines; mid of major chela palm almost colourless; rostrum, antennae, legs (except major chela) and sixth abdominal segment and tail fan semi-transparent. Ovigerous female (Fig. 6d): body, major chela, and abdominal pleurae more densely covered by network of irregularly transverse brown lines on creamy background (brown lines on carpus and fingers of minor chela, irregularly longitudinal), alternated with diffused white patches dorsally on posterior cephalothorax, and on abdominal segments III-V; cornea bright white, dense white patches distally on antennular peduncle and on base of tail-fan; distal rostrum, major parts of antennae, most pereiopods, abdominal segment VI and posterior tail-fan transparent. Juvenile specimen (Fig. 6e) semitransparent, with red patches on bases of antennae and anterior cephalothorax, posteriorly on sides of cephalothorax, and on sides of fourth abdominal segment; eyes bright white, transverse band dorsally on carapace, abdominal pleurae, and base of tail fan white.

REMARKS. See Discussion.

HOSTS. Pteroeides, Scleroblemnon, and Virgularia (Pennatularia) [Bruce, 1974; Fransen, 2012], unidentified antipatharian [Bruce, 1983], and Lytocarpia (Hydrozoa) (new host, present report: Fig. 6b).

DEPTH RANGE. 12-64 m.

DISTRIBUTION. Nhatrang Bay, Vietnam (new record), previous report from the South China Sea: Hainan [Li, 2001]; other records: Zanzibar [Bruce, 1973, 1977], Madagascar [Li, Bruce, 2006]; Borneo Bank, Indonesia (type locality) [Holthuis, 1952]; Queensland, Australia [Bruce, 1981, 1987], Semporna, Malaysia [Fransen, 2012].

\section{Dasycaris zanzibarica Bruce, 1973} Fig. $6 \mathrm{f}-\mathrm{h}$.

Dasycaris zanzibarica Bruce, 1973: 247, Figs. 1-6.

Dasycaris zanzibarica. - Bruce, 1991: 265, Fig. 27. — Marin, Savinkin, 2007: 179, 195, 196, Fig. 89B.

MATERIAL, 1 male, 1 female, UO 40-Vn10, Mun Is., Nhatrang Bay, Vietnam, 12 Aug. 2010, sandy bottom with patch reefs, from sea-whip Cirripathes sp., coll. Z. Duriš, I. Horká. — 1 male, MTQ W 33352 (fcn 150-Au10), CReefs 2010, stn LI10-100, 14 $39.7^{\prime} \mathrm{S}, 145^{\circ} 28.3^{\prime}$ E, Bommie Bay, lagoon, Lizard Is., Great Barrier Reef, Australia, 8 Sep. 2010, low slope of bommie, from Cirripathes sp., 10.9 m, coll. Z. Duriš. - 1 ovigerous female, MNHN IU-2013-10039 (fen PZD\#587-Png12), Papua-Niugini 2012, stn PR203, $05^{\circ} 10.3^{\prime} \mathrm{S}, 145^{\circ} 48.5^{\prime} \mathrm{E}$, Panab Is., Madang, Papua New Guinea, 7 Dec. 2012, slope, depth 13 m, from Cirripathes sp., coll. Z. Duriš. - 1 male, 1 ovigerous female, MNHN IU-2013-11019 (fcn PZD\#601B-Png12), Papua-Niugini 2012, stn PR211, 05 15, $5^{\prime}$ S, $145^{\circ} 47,3^{\prime}$ E, S. Yabob Is., Madang, Papua New Guinea, 8 Dec. 2012, slope, depth 16 m, from Cirripathes sp., coll. D. Uyeno.

REMARKS. All specimens examined agree in general with the original description by Bruce [1973], but they are variable in the shape and height of the dorsal carapacial lobes. An ovigerous PNG female (MNHN... 11019 ) is low-lobate dorsally on the carapace (Fig. 6f), another PNG ovigerous female (Fig. 6g) has high, slightly anteriorly recurved, dorsal lobes. The Australian male is similar to the latter female, but its lobes are lower. Instead, the Vietnamese ovigerous female (Fig. 6h) possess strong dorsal lobes, more widely triangular, erect. All PNG and Australian specimens (Fig. $6 \mathrm{f}, \mathrm{g})$ are similarly coloured bearing white antennae, eyes, pereiopods, dorsal carapacial lobes and transverse bands on carapace and abdomen, while a similar pattern but mainly yellow-brown in colour is present in the Vietnamese specimens (Fig. 6h).

Abdominal pleurae and the male first gonopods were examined in those specimens for a comparison with the above specimens of $D$. ceratops. While all available females of $D$. zanzibarica have all abdominal pleurae rounded and soft, in the males a slight variability was apparent. The posteroventral angles of pleura $\mathrm{I}-\mathrm{V}$ were acute in the single PNG male, while in the Vietnamese and Australian males pleurae IV-V are feebly pointed or rounded, respectively. Pleurae I, however, possess a very large, anteriorly produced anteroventral membranous lobe, not reported in the original description [Bruce, 1973], much larger than that in D. ceratops (above).

The endopod of the male first pleopod is undivided, generally similar to that figured by Bruce [1973: Fig. $2 \mathrm{H}$ ], but not as slender; that of the PNG male is wider, stouter.

For other remarks see the Discussion.

HOSTS. Cirripathes spp. (Cnidaria: Antipatharia). DEPTH RANGE. 4-39 m [Li, Bruce, 2006].

DISTRIBUTION. Previously reported from Nhatrang Bay, Vietnam [Marin, Savinkin, 2007; Marin, 2012], and from Lizard Island, Queensland, Australia [Bruce, 1983]. Other Indo-West Pacific records are Zanzibar [Bruce, 1973]; Madagascar, Philippines [Li, Bruce, 2006]; Semporna, Malaysia [Fransen, 2012]; Kalimantan and Ternate, Indonesia [Fransen, 2004, 
2010]; Taiwan [Jeng 1988]; Japan [Okuno, 1996]; Papua, Indonesia [Fransen, 2008]; W. Australia [Berggren, 1997]; NE Australia [Bruce, 1983]; New Caledonia [Bruce, 1991]; Madang — new record from New Guinea (present report).

\section{Discussion}

Despite a comparatively limited number of specimens of Dasycaris symbiotes, D. ceratops and D. zanzibarica having been reported up to now, a remarkably wide variability of some morphological characters have been indicated in previous reports. Among them, the shape of the rostrum and dorsal carapacial teeth or lobes seems to be the most variable. The differences in the extension of the dorsal lobes on the carapace are well illustrated by Bruce [1973] for D. zanzibarica. This species is easily distinguishable from its congeners by a completely toothless rostrum. Other species possess acute teeth on the rostrum and on the carapace. Their number, position and level of lateral compression are characters used for a separation the species [Bruce 1973; Chace, Bruce, 1993].

A well developed, styliform rostrum and dorsal carapacial teeth in the present male specimen of $D$. ceratops are similar, but stronger to that of Bruce's [1973] juvenile female mentioned above. Together with that, both are quite distinct from the original illustration of the ovigerous female holotype from Borneo by Holthuis [1952: Fig. 87a] who described, in addition to a single dorsal rostral tooth, the presence of... "four large compressed teeth; the posterior of these teeth is situated behind the middle of the carapace, the other three are placed rather close together in the anterior part of the carapace, forming a basal crest to the rostrum; the anterior tooth stands just over the orbit" [Holthuis, 1952: 176]. Such a compressed crest of teeth is mentioned also by Chace and Bruce [1993] in their identification key. The present adult male and juveniles have crest-arranged dorsal teeth, but the epigastric tooth is sharp, not triangular, and on the rostrum, anterior to the basal crest of 3 teeth, is only 1 proximal slender tooth in the Holthuis' type as well as in the present male specimen, but two in the Australian juvenile female [Bruce, 1977]. A wider series of specimens from various regions is thus necessary for morphological and molecular comparison for confirmation of conspecific status of the specimens discussed here.

Together with a general variability of the carapacial structures, intraspecific variability is also linked to distinct sexual dimorphism. As adult females are, as a rule, larger and more densely coloured, and, thus, more frequently collected than males, the descriptions of all four species were done primarily on females. Moreover, in $D$. doederleini only a single female specimen is known. Male characters have been described only for D. zanzibarica [see: Bruce, 1973] up to now. In consequence the identification keys covering all species provided by Bruce [1973] or Chace and Bruce
[1993] were based mainly on adult females, and based on rostral armament, dorsal carapacial teeth or lobes and the shape of female abdominal pleurae. Pleurae III-V are acutely produced posteroventrally in females of all species except D. zanzibarica, which may occasionally possess a small acute tooth there [Bruce, 1973; Chace, Bruce, 1993]. Abdominal pleurae I and II are posteroventrally acute in $D$. doederleini [see Balss, 1924: Fig. 2] or rounded in D. symbiotes [e.g., Kemp, 1922: P1. 9; Monod, 1976: Fig. 55], while only pleurae II are produced in D. ceratops (e.g., Holthuis, 1952: Fig.87A). Sometimes also pleurae I may bear a small posteroventral process in the latter species, as shown by Bruce [1977: Fig. 5] for the juvenile female. The presence or shape of the pleural process in females may, thus, also depend on the developmental stage of specimens, and the last three species might be confused. However, Dasycaris ceratops can be easily distinguished by the ovoid shape of the cornea from $D$. symbiotes and $D$. doederleini which have globular eyes [Chace, Bruce, 1993].

As mentioned above, male specimens have not been described in details for $D$. ceratops, $D$. doederleini, or $D$. symbiotes. The present report provides a description of an adult male of $D$. ceratops partially filling this lack. The stronger rostro-carapacial armament in the present male specimen is mentioned above. Abdominal pleurae I-V are all sharply produced ventrally or posteroventrally, with a distinct vertical keel on each lobe. Quite remarkable is a movable, membranous, anteroventral rounded plate on the abdominal pleurae (Fig. 1), not reported before. However, it is not a special male character as such a plate is also present in juvenile males from Vietnam, and may be found also in other species and sexes. At least, a similar line is feebly but visible on a photo of $D$. ceratops from the Philippines (Fig. 6c) and a feeble drawn line possibly also indicating such a suture is present in Kemp's figure of $D$. symbiotes female [Kemp, 1922: P1. 9]. A large membranous anteroventral lobe is also present in all three available male specimens of $D$. zanzibarica, from Vietnam, PNG and Australia, despite not being reported from the allotype male in the original description. Instead, Bruce [1973: 254] reported the male pleurae as calcified and rigid. As the membranous or movable plate may play role in an extension of the movement range for the last pereiopods, its presence in Dasycaris shrimps needs closer examination and might possibly also be present in the two remaining species, $D$. symbiotes and $D$. doederleini. In such a case, it could be an additional character of generic importance.

The male gonopods have been described and illustrated only for D. zanzibarica [Bruce, 1973: 254, Fig. $2 \mathrm{H}, \mathrm{I}]$. The second gonopod possesses an appendix masculina which is elongate, setose and shorter than the appendix interna, as in the present specimen of $D$. ceratops. Also the endopod of the first male gonopod has a similar elongate shape with a subcircular apex distinctly curved medially, but no subdivision was re- 
corded nor by Bruce [1973], nor in the present specimens of the species. The present adult male specimen of $D$. ceratops has a stouter and wider endopod (similar to the present specimens of $D$. zanzibarica), with the apex separated from the basal part by a distinct transverse suture. This subdivision of the endopod of the first male pleopod is possibly unique among pontoniine shrimps. Also the proximomedial setation is different in the present species ( 3 plumose setae and no simple setae, vs. $2+2$ ones, resp., in D. zanzibarica), and the distolateral setae (3 plumose ones in the present species) are not reported for $D$. zanzibarica.

Another undescribed structure is the fine denticulation distally on the cutting edges of the first pereiopods fingers in the present specimen of D. ceratops (Fig. $4 b, c)$. There is no mention of such denticles in the original description of the species by Holthuis [1952]. Such structure is not known for any other species of the genus. Only D. zanzibarica possess 3-4 small tooth there [Bruce, 1973; same on the present specimens examined], while for $D$. symbiotes the cutting edges were originally reported as unarmed [Kemp, 1922], but for $D$. doederleini the ornamentation of those cutting edges remains unknown.

\section{Acknowledgements}

The material was collected during the following expeditions: (1) summer field research trips to Vietnam, 2006-2013, in co-operation with A.N. Severtzov Institute of Ecology and Evolution, RAS, Moscow, Russia, and the Vietnam-RussianTropical Center in Nhatrang City, Vietnam (principal investigator - T. Britaev); (2) CReefs Lizard Island Expedition 2010, a part of the CReefs Australia - a partnership between the Australian Institute of Marine Science, BHP Billiton, the Census of Marine Life, and the Great Barrier Reef Foundation project (principal investigators - J. Caley and S. Smith, AIMS, Townsville); (3) Madang, 2012, part of Our Planet Reviewed, Papua-Niugini Expedition, organized jointly by the MNHN, Pro Natura International, the Institut de Recherche pour le Développement, and the University of Papua New Guinea (principal investigators - P. Bouchet, S. Samadi, and C. Payri); funded by the Total Foundation, Prince Albert II of Monaco Foundation, Foundation EDF, Stavros Niarchos Foundation, and Entrepose Contracting; supported by the Divine Word University, permit delivered by the Papua New Guinea Department of Environment and Conservation.

I also thank S. De Grave (Oxford University Museum of Natural History, UK) for reading the manuscript, A. Anker (Museum of Zoology, University of São Paulo, Brazil) and A. Ryanskiy (Moscow, Russia) for kindly providing colour photographs, and I. Horká and A. Šobáňová (UO) for assistance with figure arrangement.

This work was supported by the project IET (CZ. $1.05 / 2.1 .00 / 03.0100)$ financed by the Structural Funds of the European Union and Project LO1208 of the National Feasibility Programme-I of the Czech Repub- lic, and the Czech National Committee for cooperation with IOC UNESCO.

\section{References}

Balss H. 1924. Ostasiatische Decapoden // Archiv für Naturgeschichte. Bd.90A. H.5. S.20-84.

Berggren M. 1997. The shrimps from the reefs off the Kimberley, Western Australia // D.I. Walker (ed.). Marine Biological Survey of the Central Kimberley Coast, Western Australia. University of Western Australia (unpublished report). P.86-90.

Bruce A.J. 1973. Notes on some Indo-Pacific Pontoniinae, XXIV. Dasycaris zanzibarica sp. nov. from the western Indian Ocean, with remarks on ther species of Dasycaris Kemp, 1922 (Decapoda Natantia) // Crustaceana. Vol.24. P.247-260.

Bruce A.J. 1974. A synopsis of the pontoniinid shrimp fauna of central East Africa // Journal of the Marine Biological Association of India. Vol.16. No.2. P.462-490.

Bruce A.J. 1977. A Report on a Small Collection of Pontoniine Shrimps from Queensland, Australia // Crustaceana. Vol.33. No.2. P.173-174.

Bruce A.J. 1981. Pontoniine shrimps of Heron Island //Atoll Research Bulletin. Vol.245. P.1-33.

Bruce A.J. 1983. The pontoniine shrimp fauna of Australia // J.K. Lowry (ed.). Papers from the Conference on the biology and evolution of Crustacea, Australian Museum, Sydney, 1980 // Memoirs of the Australian Museum. Vol.18. P.195-218.

Bruce A.J. 1990. Recent additions to the pontoniine shrimp fauna of Australia // The Beagle, Records of the Northern Territory Museum of Arts and Sciences. Vol.7. No.2. P.9-20.

Bruce A.J. 1991. Shallow-water Palaemonoid shrimps from New Caledonia (Crustacea: Decapoda) // B. Richer de Forges (ed.). Le benthos de fonds meubles des lagons de Nouvelle-Calédonie. Paris: L'ORSTOM. Vol.1. P.149-219.

Chace F.A.J., Bruce A.J. 1993. The caridean shrimps (Crustacea: Decapoda) of the Albatross Philippine Expedition 1907-1910, Part 6: Superfamily Palaemonoidea // Smithsonian Contributions to Zoology. No.543. P.1-152.

Fransen C.H.J.M. 2004. Pontoniine shrimps // B.W. Hoeksema (ed.). Marine biodiversity of the coastal area of the Berau region, East Kalimantan, Indonesia. Progress Report, East Kalimantan Program - Pilot phase (October 2003). Leiden: NNHM-Naturalis. P.19-21.

Fransen C.H.J.M. 2008. Pontoniine shrimps // B.W. Hoeksema \& S.E.T van der Meij (eds.). Cryptic marine biota of the Raja Ampat island group. Preliminary result of the Raja Ampat Expedition (2007), Ekspedisi Widza Nusantra (E-Win) of the Indonesian Institute of Science (LIPI). Progress Report. Naturalis, LIPI. P.16-18.

Fransen C.H.J.M. 2010. Palaemonoid Shrimps // B.W. Hoeksema \& S.E.T van der Meij (eds.). Preliminary results of the Ternate Expedition (2009). Naturalis, LIPI. P.26-30.

Fransen C.H.J.M. 2012. Palaemonoid Shrimps // K. Kassem, B. Hoeksema \& Y.A. Affendi (eds.). Semporna Marine Ecological Expedition. Kota Kinabalu, Malaysia: WWF-Malaysia, NCB Naturalis, Universiti Malaysia Sabah. P.101-108,

Holthuis L.B. 1952. The Decapoda of the Siboga Expedition. Part XI. The Palaemonidae collected by the Siboga and Snellius Expeditions with remarks on other species II. Subfamily Pontoniinae // Siboga Expeditie. Vol.39. No.a ${ }^{10}$. P.1-253.

Jeng M.S. 1998. [Shrimps and crabs of the Kentin National Park]. Ping-Tong, Taiwan: The Kentin National Park. 133 p. [in Chinese].

Kemp S. 1922. Notes on Crustacea Decapoda in the Indian Museum, XV. Pontoniinae // Records of the Indian Museum. Vol. 24. P. 113-288, Pls. 1-9.

Li X., Bruce A.J. 2006. Further Indo-Pacific palaemonoid shrimps (Crustacea: Decapoda: Palaemonoidea), principally from the New Caledonian region // Journal of Natural History. Vol.40. P.611-738. 
Marin I.N. 2012. New records and associations of pontoniine shrimps (Crustacea: Decapoda: Caridea: Palaemonidae: Pontoniinae) from the Nhatrang Bay, Vietnam; with taxonomic remarks on some species from the Indo-West Pacific region // T.A. Britayev \& D.S. Pavlov (eds.). Benthic fauna of the Bay of Nhatrang, Southern Vietnam. Moscow: KMK Sci. Press. Vol.2. P.345-405.

Marin I., Savinkin O. 2007. Further records and preliminary list of pontoniine (Caridea: Palaemonidae: Pontoniinae) and hymenocerid (Caridea: Hymenoceridae) shrimps from Nhatrang Bay // T. Britayev \& D. Pavlov (eds.). Benthic Fauna of the Bay of
Nhatrang, Southern Vietnam. Moscow: KMK Sci. Press. P.176208.

Monod T. 1976. Sur une nouvelle collection de crustacés décapodes de Nouméa (Nouvelle-Calédonie) // Cahiers du Pacifique. Vol.19. P.133-152.

Okuno J. 1996. [First record of a pontoniine shrimp, Dasycaris zanzibarica Bruce, 1973 from Japan (Crustacea: Decapoda)] // Izu Ocean Park Div. News. Vol.7. No.7. P.2-4 [in Japanese, with English abstract].

Responsible editor V.A. Spiridonov 